\section{'Cebasred' and 'Primorosa' Apricots: Two New Self-compatible, Plum pox virus (Sharka)-resistant, and Very Early Ripening Cultivars for the Fresh Market}

\author{
David Ruiz', Manuel Rubio, Pedro Martínez-Gómez, \\ Jesús López-Alcolea, Federico Dicenta, Encarna Ortega, \\ María Dolores Nortes, Antonio Molina, Antonio Molina Jr., \\ and Jose Egea \\ Departamento de Mejora Vegetal, Centro de Edafología y Biología Aplicada \\ del Segura-Consejo Superior de Investigaciones Cientificas (CEBAS-CSIC), \\ P.O. Box 164, Espinardo, Murcia E-30100, Spain
}

Additional index words. apricot breeding, Prunus armeniaca, extra-early ripening, Plum pox virus resistance, self-compatibility, fruit quality

'Cebasred' and 'Primorosa' are very early-season ripening apricot cultivars (Prunus armeniaca L.) which join high productivity, high fruit quality and attractiveness, with resistance to Plum pox virus (PPV), a valuable characteristic due to the growing incidence of sharka disease caused by this virus in the European apricot orchards (Rubio et al., 2017). In addition, 'Cebasred' and 'Primorosa' are self-compatible cultivars. 'Cebasred' and 'Primorosa' combine all the above mentioned characteristics with very low chilling requirements, which also let them to be cultivated in warm areas. These new varieties will contribute to broaden the ripening calendar with highly valuable sharka resistant germplasm also ready to be used in future breeding processes for low chilling warmer areas.

\section{Origin}

'Cebasred' resulted from a cross made in 2012 at CEBAS-CSIC of Murcia (Spain) between the apricot breeding line '1100-526' (female parent), which was obtained from the CEBAS-CSIC breeding program, and the Spanish cultivar, of unknown origin, Colorado (male parent) (Fig. 1). This cross was made with the objective of obtaining selfcompatibility, extra-early season ripening, and sharka (PPV)-resistant cultivars, as well as excellent fruit quality and optimal productivity level to replace traditional cultivars in areas affected by this viral disease (Egea et al., 1999). 'Primorosa' resulted from a cross

Received for publication 2 July 2018. Accepted for publication 25 Sept. 2018.

The work has been financed with several projects of the "Plan Nacional de I+D" of the Spanish Ministry of Science and Technology from 1985, the last one being entitled "Mejora Genética del Albaricoquero" (AGL2017-86627-R).

${ }^{1}$ Corresponding author. E-mail: druiz@cebas.csic.es. made in 2010 at Murcia (Spain) between the apricot cultivar Rojo Pasión (female parent), which was obtained from the CEBAS-CSIC breeding program (Egea et al., 2004), and the Spanish cultivar, of unknown origin, Búlida Precoz (male parent) (Fig. 1). This cross was also made with the objective of obtaining selfcompatibility, early ripening, sharka resistance, and excellent fruit quality. 'Cebasred' and 'Primorosa' were selected as seedling trees on their own roots and then grafted onto 4-year-old apricot seedlings (Prunus armeniaca L.) rootstocks (three replications each) for agronomical evaluation.

\section{Description}

\section{Tree characteristics}

Tree description. Trees are vigorous with medium-upright habit for 'Cebasred' and
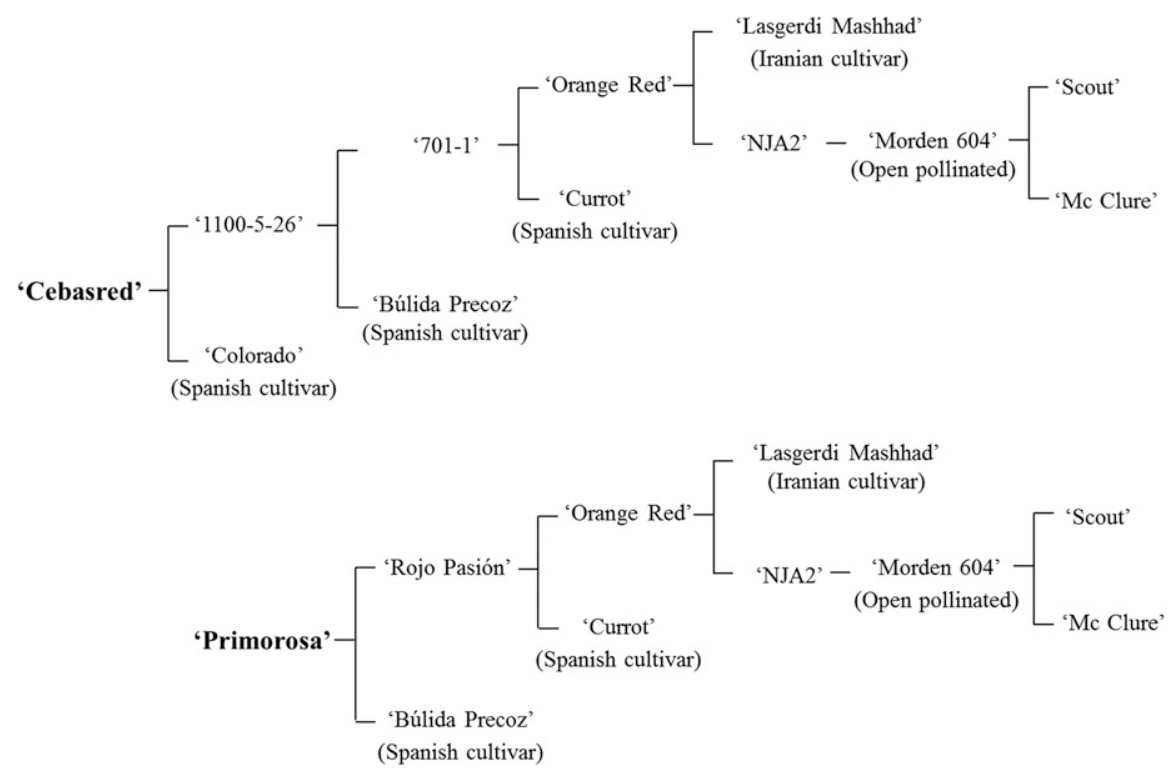

Fig. 1. Pedigree of apricot cultivars Cebasred and Primorosa. moderately spreading habit for 'Primorosa' trees. This tree architecture greatly facilitates pruning (reduced branching habit). 'Cebasred' and 'Primorosa' have a high and medium flower density, respectively. Both cultivars are characterized by their high productivity level in comparison with some traditional Spanish cultivars. Fruit production in 'Cebasred' occurs mainly on fruiting spurs of 2-year-old branches, whereas in 'Primorosa' the fruit production is located both in spurs of 2-year-old branches and brindles. They have a moderate need for thinning to obtain good fruit sizes (Table 1).

Plum pox virus resistance. All apricot cultivars traditionally grown in Europe are susceptible to sharka disease caused by PPV, whereas several cultivars from North America such as 'Goldrich', 'Sunglo', 'Orange Red', and 'Stark Early Orange' showed resistance to PPV (Martínez-Gómez et al., 2000) and are frequently used as parents in breeding programs (Egea et al., 1999). In the case of 'Cebasred' and 'Primorosa', the CEBAS-CSIC apricot breeding line ' $701-1$ ' and 'Rojo Pasión' cultivar were used, respectively, as parents to obtain PPV resistance (Fig. 1). The evaluation of PPV resistance was carried out in greenhouse conditions by grafting onto PPV-infected 'GF305' peach seedlings growing in pots and by grafting onto infected 7-year-old apricot trees strongly affected by the disease growing in a quarantine shelter (Rubio et al., 2009). Phenotyping against PPV in both conditions showed the resistance of 'Cebasred' and 'Primorosa' to PPV Dideron-type isolate 3.30 RB/GF-IVIA (GenBank: KJ849228.1) (absence of symptoms and ELISA-DASI and RT-PCR negatives in leaves), in comparison with the susceptibility of the traditional Spanish cultivars (Table 1).

Chilling requirements and blooming time. 'Cebasred' and 'Primorosa' need $\approx 38$ chill portions according to the Dynamic Model (Fishman et al., 1987a, 1987b) to break 
Table 1. Description of tree and fruit traits of 'Cebasred' and 'Primorosa', the traditional Spanish cultivars Currot and Búlida, and the North American cultivar Orange Red under experimental conditions in Cieza (Murcia, Southeast Spain).

\begin{tabular}{|c|c|c|c|c|c|}
\hline Characteristics & Cebasred & Primorosa & Currot & Búlida & Orange Red \\
\hline & \multicolumn{5}{|c|}{ Tree } \\
\hline Vigor & Vigorous & Vigorous & Vigorous & Very vigorous & Vigorous \\
\hline Habit & Medium-upright & Moderately spreading & Moderately spreading & Moderately spreading & Moderately spreading \\
\hline Flower density & High & Medium & High & Medium & Low \\
\hline Flowering date & 18 Feb. & 20 Feb. & $18 \mathrm{Feb}$ & 8 Mar. & 15 Mar. \\
\hline Self-compatibility & Self-compatible & Self-compatible & Self-compatible & Self-compatible & Self-incompatible \\
\hline Yield (1-9) & 9 & 9 & 8 & 9 & 5 \\
\hline Level of thinning & Moderate & Moderate & Low & High & Low \\
\hline \multirow[t]{2}{*}{$\begin{array}{l}\text { Resistance to Plum } \\
\text { pox virus }\end{array}$} & Yes & Yes & No & No & Yes \\
\hline & \multicolumn{5}{|c|}{ Fruit } \\
\hline Ripening date & 30 Apr. & 6 May & 7 May & 26 May & 28 May \\
\hline Fruit weight (g) & 64.0 & 75.2 & 53.8 & 63.8 & 61.0 \\
\hline Firmness & Very High & High & Medium & Medium & High \\
\hline Skin color & Orange (red blush) & Light orange (red blush) & White & Light orange & Orange (red blush) \\
\hline Red blush (\%) & 45.0 & 25.0 & 15.0 & 10.0 & 45.0 \\
\hline Flesh color & Orange & Light orange & White & Light orange & Orange \\
\hline Sugar $\left({ }^{\circ}\right.$ Brix $)$ & 11.3 & 13.4 & 13.1 & 11.6 & 14.2 \\
\hline Acidity $(\mathrm{g} / 100 \mathrm{~mL})^{\mathrm{z}}$ & 1.34 & 1.28 & 1.20 & 1.29 & 1.23 \\
\hline
\end{tabular}

${ }^{\mathrm{z}}$ Titratable acidity expressed as grams of malic acid/100 mL of juice.

dormancy under our conditions in Murcia (southeast of Spain, lat. $37^{\circ} \mathrm{N}$, long. $1^{\circ} \mathrm{W}$, and $350-\mathrm{m}$ altitude). Therefore, these new cultivars show very low chilling requirements (Ruiz et al., 2007). Full bloom for 'Cebasred' and 'Primorosa' occurs on average on 18 Feb. and 20 Feb. respectively, a very early flowering date similar to that of the traditional Spanish cultivar Currot (Table 1).

Floral compatibility. 'Cebasred' and 'Primorosa' are self-compatible as demonstrated in the field (by bagging branches) and in the laboratory (by observing pollen tube growth in 10 flowers) according the methodology described by Burgos et al. (1993). In addition, the identification of their $S$ genotypes by PCR using the consensus primers EM-PC2consFD and EM-PC3consRD (Sutherland et al., 2004) revealed that 'Primorosa' is homozygous for self-compatibility $(\mathrm{ScSc})$, whereas 'Cebasred' is heterozygous for self-compatibility, showing the band corresponding to the Sc RNase allele and a band of 300 bp (agarose gel electrophoresis not shown).

\section{Fruit characteristics}

Ripening time. The ripening date for 'Primorosa' in our experimental conditions in Murcia (southeast of Spain, lat. $37^{\circ} \mathrm{N}$, long. $1^{\circ} \mathrm{W}$, and $350-\mathrm{m}$ altitude) is $\approx 6 \mathrm{May}$, similar to the earliest ripening traditional Spanish cultivar Currot and the very early ripening releases from CEBAS-CSIC 'Mirlo Blanco' and 'Mirlo Anaranjado' (Egea et al., 2010). The ripening date for 'Cebasred' is $\approx 30 \mathrm{Apr}$., around $7 \mathrm{~d}$ earlier than 'Primorosa' and Currot, $\approx 26 \mathrm{~d}$ earlier than the Spanish cultivar Búlida, and $28 \mathrm{~d}$ earlier than the North American cultivar Orange Red (Table 1). This means that 'Cebasred' is considered as an extra-early cultivar with the earliest date of ripening of all the apricot cultivars grown in Spain. Fruit of both cultivars ripen uniformly. At that time in the season, there is very limited competition with apricots produced from other European countries, mainly in the case of 'Cebasred'.
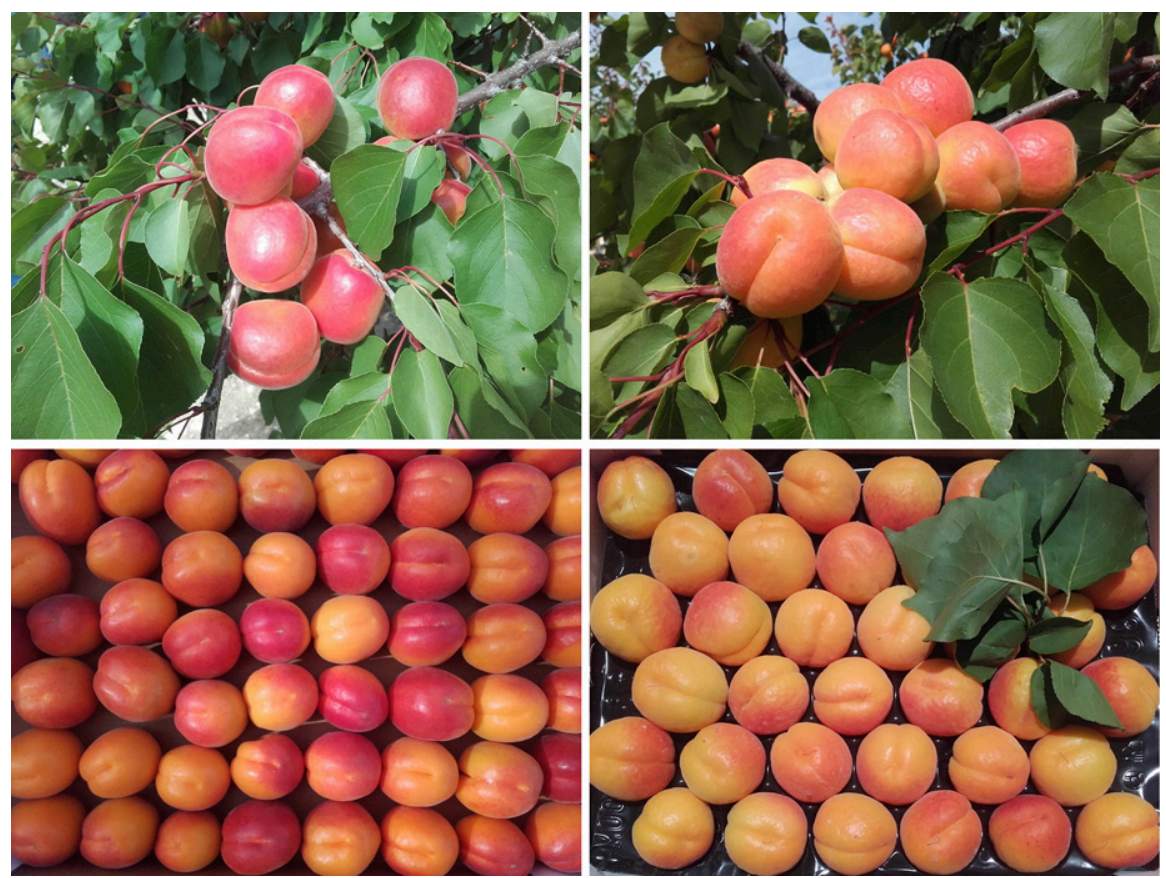

Fig. 2. 'Cebasred' (left) and 'Primorosa' (right) fruits in the tree and after harvesting.

Fruit description. 'Cebasred' and 'Primorosa' trees and reference cultivar trees ('Currot', 'Búlida', and 'Orange Red') were grown in the same orchard according to standard apricot orchard management. Fruit characterization was made at commercial ripening on the basis of their visual skin ground color (degreening stage and fully colored). Three replications of 10 fruits each were selected for each cultivar and year. 'Cebasred' bears slightly oblong fruits with an average weight of $64.0 \mathrm{~g}$, which means significantly larger fruits than the early ripening reference cultivar Currot and quite similar to the reference cultivars Búlida and Orange Red. 'Primorosa' bears large and globose fruits with an average weight of
$75.2 \mathrm{~g}$, larger than all the early ripening cultivars grown to date and larger than the reference cultivars Búlida and Orange Red (Table 1; Fig. 2). 'Cebasred' and 'Primorosa' are characterized by high fruit firmness at commercial ripening when they were harvested, improving the firmness of Spanish traditional cultivars Currot and Búlida. Both new releases are skin cracking resistant as it was corroborated in the years 2016 and 2017 with rainfall conditions ( $30 \mathrm{~mm}$ in 2017) just before the time of fruit ripening. Fruits of the two new cultivars are freestone and not susceptible to pit burning (flesh browning close to the stone). 'Cebasred' fruit has orange skin ground color and the fruit surface is covered by an extensive and intense red 
blush (Fig. 2), in contrast to the early traditional Spanish cultivar Currot characterized by white coloration and quite similar to the cultivar Orange Red (Table 1). 'Primorosa' fruit has light orange skin ground color and the fruit surface is covered by a light red blush (Fig. 2). The flesh color for 'Cebasred' and 'Primorosa' is orange and light orange, respectively.

Organoleptic characteristics. At commercial maturity stage, 'Cebasred' fruits are moderately sweet $\left(11.3^{\circ}\right.$ Brix on average), similar to the Spanish traditional cultivar Búlida and less sweet than the reference cultivars Currot and Orange Red, with medium level of acidity (1.34 $\mathrm{g}$ of malic acid/100 $\mathrm{mL}$ of juice) and a good eating quality (Table 1). 'Primorosa' fruits are sweet $\left(13.4^{\circ}\right.$ Brix on average), similar to the early ripening Spanish traditional cultivar Currot, with low-medium level of acidity (1.28 $\mathrm{g}$ of malic acid/100 $\mathrm{mL}$ of juice) and a very good eating quality (Table 1).

\section{Availability}

'Cebasred' and 'Primorosa' are registered in the European Union Community Plant
Variety Office with the registration numbers 2017/2703 and 2017/2704, respectively. Virus-free budwoods are available from CEBAS-CSIC (Spain) tested as free of Prunus necrotic ringspot virus, Apple mosaic virus, Apple chlorotic leaf spot virus, Prune dwarf virus, and PPV.

\section{Literature Cited}

Burgos, L., T. Berenguer, and J. Egea. 1993. Selfand cross-compatibility among apricot cultivars. HortScience 28:148-150.

Egea, J., L. Burgos, P. Martínez-Gómez, and F. Dicenta. 1999. Apricot breeding for sharka resistance at CEBAS-CSIC, Murcia (Spain). Acta Hort. 488:153-157.

Egea, J., F. Dicenta, and L. Burgos. 2004. 'Rojo Pasión’ apricot. HortScience 39:1490-1491.

Egea, J., A. Molina, M. Rubio, P. Martínez-Gómez, J.A. Campoy, E. Ortega, M.D. Nortes, A Molina, Jr., F. Dicenta, and D. Ruiz. 2010. 'Mirlo Blanco', 'Mirlo Anaranjado' and 'Mirlo Rojo': Three new very early apricots for the fresh market. HortScience 45:1893-1894.

Fishman, S., A. Erez, and G.A. Couvillon. 1987a. The temperature dependence of dormancy breaking in plants: Mathematical analysis of a two-step model involving a cooperative transition. J. Theor. Biol. 124:473-483.

Fishman, S., A. Erez, and G.A. Couvillon. 1987b. The temperature dependence of dormancy breaking in plants: Computer simulation of processes studied under controlled temperatures. J. Theor. Biol. 126:309-321.

Martínez-Gómez, P., F. Dicenta, and J.M. Audergon. 2000. Behaviour of apricot (Prunus armeniaca L.) cultivars in the presence of sharka (Plum pox potyvirus): A review. Agronomie 20:407422.

Rubio, M., A. García-Ibarra, P. Martínez-Gómez, and F. Dicenta. 2009. Analysis of the main factors involved in the evaluation of Prunus resistance to Plum pox virus (Sharka) in control greenhouse conditions. Scientia Hort. 123:4650.

Rubio, M., P. Martínez-Gómez, A. Marais, J.A. Sánchez-Navarro, V. Pallás, and T. Candresse. 2017. Recent advances and prospects in Prunus virology. Ann. Appl. Biol. 171:125-138.

Ruiz, D., J.A. Campoy, and J. Egea. 2007. Chilling and heat requirements of apricot cultivars for flowering. Environ. Expt. Bot. 61:254-263.

Sutherland, B.G., T.P. Robbins, and K.R. Tobutt. 2004. Primers amplifying a range of Prunus $S$ alleles. Plant Breed. 123:582-584. 